\title{
SISTEM PENCATATAN POIN PELANGGARAN SISWA PADA SMA NEGERI 1 PURWOSARI
}

\author{
Dwi Setyawan', Ely Setyo Astuti', Ekojono ${ }^{3}$ \\ ${ }^{1,2,3}$ Prodi Teknik Informatika, Jurusan Teknik Elektro, Politeknik Negeri Malang \\ uwauwan@gmail.com
}

\begin{abstract}
Abstrak
Tingkat pelanggaran siswa pada SMA Negeri 1 Purwosari dari tahun ke tahun terus bertambah dengan berbagai macam pelanggaran yang dilakukan. Selama ini pencatatan poin pelanggaran yang dilakukan oleh guru BK (Bimbingan Konseling) menggunakan buku tatib yang dimiliki oleh sekolah.

Pengendalian pada pelanggaran yang dilakukan masih belum dapat dilakukan secara optimal karena guru BK (Bimbingan Konseling) tidak dapat dengan mudah menentukan tingkat tertinggi pelanggaran yang dilakukan oleh siswa. Karena itulah sebuah sistem pencatatan poin pelanggaran siswa pada sekolah sangat diperlukan untuk mengetahui tingkat ketidak disiplinan para siswa dalam lingkungan sekolah. Sistem informasi tersebut juga dapat menghasilkan informasi tersebut secara efektif dan efisien.

Sistem pencatatan pelangaran ini menggunakan metode penjumlahan dari tiap komponen pelanggaran yaitu komponen sikap dan perilaku, komponen kerajinan dan komponen kerapian, sehingga nanti didapatkan jumlah point dari tiap siswa beserta sanksi yang didapat dan jumlah statistik pelanggaran yang dilakukan oleh siswa. Dengan demikian sistem pencatatan poin pelanggaran ini dapat menjadi pendukung keputusan bagi guru BK yang memberi penilaian terhadap pelanggaran siswa di lingkungan sekolah.
\end{abstract}

\section{Kata Kunci : Sistem Pencatatan Poin, Point Pelanggaran, Sistem Informasi}

\section{Pendahuluan}

Di era globalisasi ini banyak kita jumpai berbagai masalah yang timbul dalam kehidupan sehari-hari. Mulai dari masalah ekonomi, sosial, pendidikan dan masih banyak lagi. Dalam segi pendidikan di Indonesia, masalah-masalah yang timbul masih sangat banyak. Salah satunya yaitu masalah yang berkaitan dengan kenakalan remaja di sekolah. Masa remaja adalah masa peralihan dari masa anak ke masa dewasa. Pada saat masa peralihan seperti ini, cara berpikir remaja cenderung labil. Mereka sering mengikuti tingkah teman sebayanya, tanpa berpikir benar atau salah. Yang terpenting adalah kepuasan pada diri mereka. Remaja sekarang lebih cenderung bersenang-senang dan berfoya-foya. Mereka tidak mempedulikan akibat dari apa yang mereka lakukan.

Lembaga pendidikan di Sekolah Menengah Atas merupakan tempat untuk membentuk serta mendidik generasi muda, tetapi selama ini masih banyak siswa dan siswi yang melakukan tindakan melanggar aturan-aturan ataupun kedispilinan yang sudah ditetapkan sekolah tersebut. Pelanggaran yang dilakukan para siswa tidak hanya di lakukan di dalam sekolah tetapi juga dilakukan di luar sekolah sehingga ada bermacam-macam jenis pelanggaran yang di langgar oleh para siswa. Disinilah peran guru dan orang tua / wali murid sangat diperlukan dalam proses pendidikan siswa dan siswi demi menjaga dari pengaruh kenakalan remaja tetapi orang tua / wali murid terkadang kesulitan untuk mengetahui pelanggaran yang sudah dilakukan oleh anak mereka secara detail.
Sistem poin untuk pelanggaran adalah salah satu sistem yang cukup efektif untuk meningkatkan ketertiban siswa di sekolah. Kelebihan dari sistem poin ini diantaranya dapat menaggulangi tindak kekerasan fisik yang mungkin terjadi di sekolah. Selain itu juga terjalinnya komunikasi antara pihak sekolah dengan orang tua siswa dalam mengawasi anaknya sehingga tidak lagi melakukan pelanggaran di sekolah. Sistem poin ini juga tidak menimbulkan efek yang negatif bagi para siswa. Dengan adanya kebijakan ini, siswa dapat lebih berhati-hati dalam bertingkah laku di sekolah. Siswa akan berfikir kembali untuk melakukan kesalahan atau pelanggaran terhadap tata tertib sekolah.

Semakin berkembangnya sistem pencatatan saat ini, di manfaatkan pula oleh SMA Negeri 1 Purwosari untuk mengembangkan sistem informasinya yaitu pada pengolahan data, penyampaian informasi dan pengaksesan data para siswa yang melanggar selama melakukan aktivitas di sekolah pada orang tua / wali murid. Nantinya sistem pencatatan ini akan memberikan informasi detail pelanggaran yang di lakukan oleh siswa dan berapa poin yang sudah didapatkan serta bagaimana tindakan pihak sekolah setelah anak meraka mendapatkan poin poin tertentu. Sistem pencatatan tersebut diharapkan dapat membantu sekolah dalam mengevaluasi aktivitas siswanya.

Sehingga berdasarkan latar belakang di atas, penulis melakukan analisa dan mengamatan dengan mengambil judul "SISTEM PENCATATAN POIN PELANGGARAN SISWA PADA SMA NEGERI 1 PURWOSARI". 


\section{Metode}

Metode yang digunakan dalam penelitian ini mengacu pada proses pembangunan system informasi pada umumnya, yaitu dengan konsep System Development Life Cycle(SDLC). Penekanan dilakukan pada proses identifikasi masalah dan analisis perancangan serta pengujian aplikasi. Pemenuhan konsep dilakukan dengan pengumpulan data ke SMA tersebut, dengan studi pustaka dan konsultasi dengan guru bimbingan konseling (BK). Basis data dilakukan dengan analisis dan perancangan menggunakan model diagram konteks, Data Flow Diagram (DFD), dan Entity Relationalship Diagram (ERD). Untuk konsep menentuk sanksi yang dilakukan dengan menjumlah pelanggaran yang dilakukan dari komponen - komponen yang sudah di tetapkan di SMA Negeri 1 Purwosari. Selain itu pengembangan dan pembangunan aplikasi digunakan PHP dan MySQL sebagai tools language dalam konstruksinya.

\subsection{Pengumpulan Data}

Pengumpulan data dilakukan dengan melakukan survey ke sekolah dengan menemui pihak-pihak terkait seperti Guru BK, guru bagian kesiswaan dan Kepela Sekolah. Dari proses survey, data yang didapat berupa berkas document komponen poin pelanggaran dan sanksi yang di dapatkan.

\section{a. Komponen Kerajinan}

\begin{tabular}{|l|l|c|}
\hline NO & JENIS PELANGGARAN & POINT \\
\hline 1 & $\begin{array}{l}\text { Tidak mengikuti upacara tanpa } \\
\text { ijin }\end{array}$ & 1 \\
\hline 2 & $\begin{array}{l}\text { Meninggalkan jam pelajaran } \\
\text { tanpa ijin }\end{array}$ & 1 \\
\hline 3 & $\begin{array}{l}\text { Meninggalkan buku pelajaran } \\
\text { dengan sengaja didalam kelas }\end{array}$ & 2 \\
\hline 4 & Tidak melaksanakan piket & 1 \\
\hline
\end{tabular}

\section{b. Komponen Kerapian}

\begin{tabular}{|l|l|c|}
\hline NO & JENIS PELANGGARAN & POINT \\
\hline 1 & Pakaian dan atribut di corat-coret & 2 \\
\hline 2 & $\begin{array}{l}\text { Tidak berpakaian rapi atau baju } \\
\text { dikeluarkan }\end{array}$ & 1 \\
\hline 3 & \begin{tabular}{l} 
Tidak memakai sepatu hitam 1x \\
\hline 4
\end{tabular} & $\begin{array}{l}\text { Tidak memakai sepatu hitam 2x } \\
\text { sepatu disita }\end{array}$ \\
\hline
\end{tabular}

\section{c. Komponen Sikap dan Perilaku}

\begin{tabular}{|l|l|c|}
\hline NO & JENIS PELANGGARAN & POINT \\
\hline 1 & $\begin{array}{l}\text { Menyerang guru atau personil } \\
\text { sekolah }\end{array}$ & 30 \\
\hline 2 & $\begin{array}{l}\text { Hamil atau menghamili di luar } \\
\text { nikah }\end{array}$ & 40 \\
\hline 3 & $\begin{array}{l}\text { Mengancam, mengintimidasi } \\
\text { siswa lain, karyawan, guru dan } \\
\text { kepala sekolah }\end{array}$ & 5 \\
\hline 4 & $\begin{array}{l}\text { Makan dan minum pada saat } \\
\text { PBM }\end{array}$ & 1 \\
\hline
\end{tabular}

\section{d. Sanksi}

\begin{tabular}{|c|c|c|}
\hline NO & JUMLAH POINT & SANKSI \\
\hline 1 & 1 sampai dengan 5 & $\begin{array}{ll}\text { Peringatan lisan } \\
\text { oleh setiap guru } \\
\text { walikelas }\end{array}$ \\
\hline 2 & 5,5 sampai dengan 15 & $\begin{array}{l}\text { Peringatan tertulis } \\
\text { (tim tatib, BK } \\
\text { bersama } \\
\text { walikelas) }\end{array}$ \\
\hline 3 & 15,5 sampai dengan 20 & $\begin{array}{lr}\text { Skorsing } & / \\
\text { dikembalikan } & \text { ke } \\
\text { orang } & \text { tua } \\
\text { maksimal 4 hari } \\
\text { diberi tugas }\end{array}$ \\
\hline 4 & $\begin{array}{lll}20,5 & \text { sampai dengan } \\
29,5 & & \end{array}$ & $\begin{array}{lr}\text { Skorsing } & / \\
\text { dikembalikan } & \text { ke } \\
\text { orang } & \text { tua } \\
\text { maksimal } 6 & \text { hari } \\
\text { diberi tugas } & \\
\end{array}$ \\
\hline & $\begin{array}{l}30 \text { hasil perhitungan } \\
\text { komulatif }\end{array}$ & $\begin{array}{l}\text { Siswa tidak naik } \\
\text { kela. }\end{array}$ \\
\hline 5 & Poin 40 langsung & $\begin{array}{l}\text { Dikembalikan } \\
\text { kepada orang tua } \\
\text { seterusnya. }\end{array}$ \\
\hline
\end{tabular}

\subsection{Perhitungan Poin}

Untuk melakukan perhitungan poin pelanggaran yang di dapat oleh tiap siswa yaitu dengan melalukan penjumlah pada setiap pelanggaran yang dilakukan seperti di bawah ini

$\sum \mathrm{p}=\mathrm{p} 1+\mathrm{p} 2+\mathrm{p} 3 \ldots \mathrm{pn}$

keterangan

$\sum \mathrm{p}$ : Jumlah pelanggaran

Pn : jumlah pelanggaran

Jumlah Poin nantinya akan di sesuaikan dengan range poin pelanggaran yang akan di dapat sehingga nanti mendapatkan yang sesuai dengan sanksi yang sudah di tentukan pada data sanksi 


\subsection{Pemodelan Sistem}

\section{Use Case Diagram}
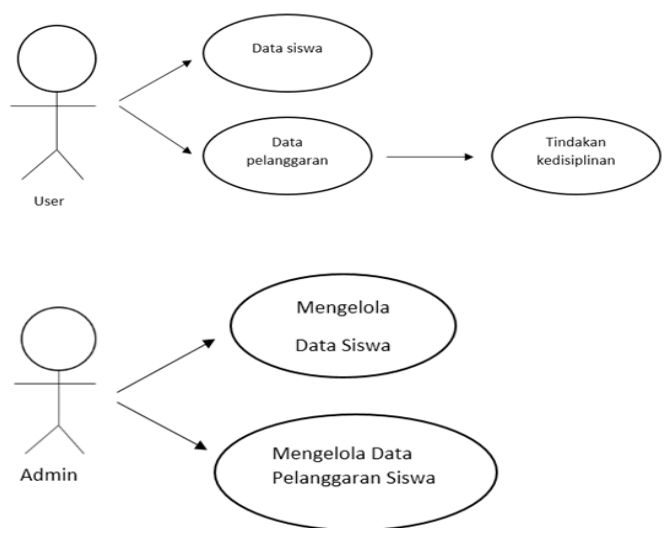

Gambar 1. Use Case Diagram

\section{Work Breakdown System}

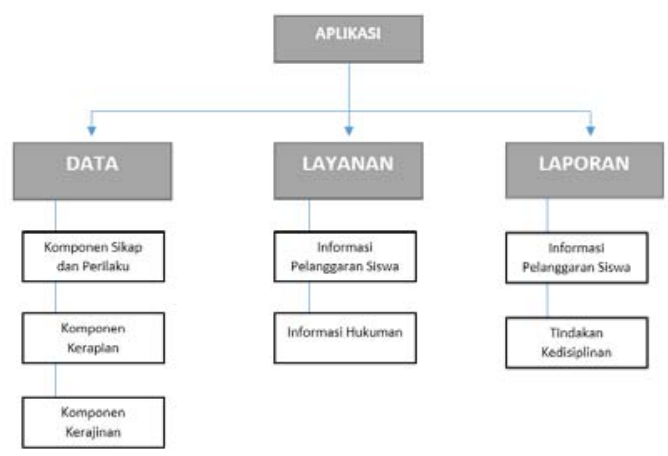

Gambar 2. Work breakdown Sytem

\section{Context Diagram}

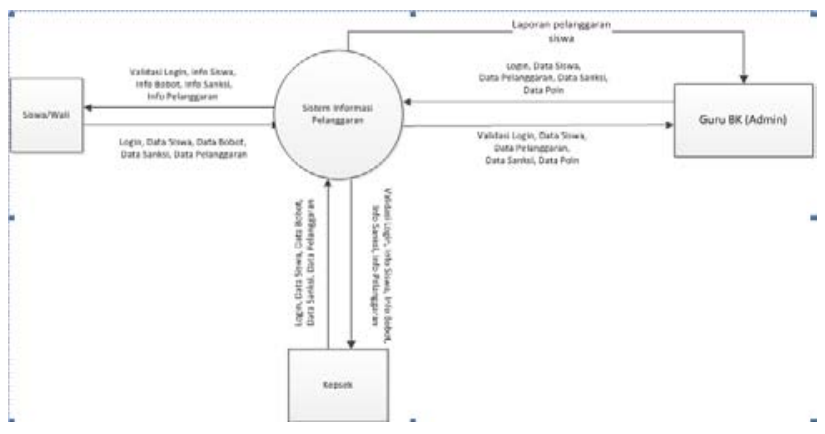

Gambar 3. Context Diagram

\section{Hasil}

Untuk menguji kualitas dari hasil penjumlahan pelanggaran yang dilakukan ataupun sanksi yang diberikan oleh system, maka diperlukan pengujian hasil. Pengujian hasil dilakukan dengan mencocokan keputusan hasil eksekusi aplikasi dengan penjumlahan dari pelanggaran yang dilakukan dari setiap komponen.

\section{a. Login}

Pada proses ini pengguna harus memasukkan username dan password, lalu klik tombol Enter

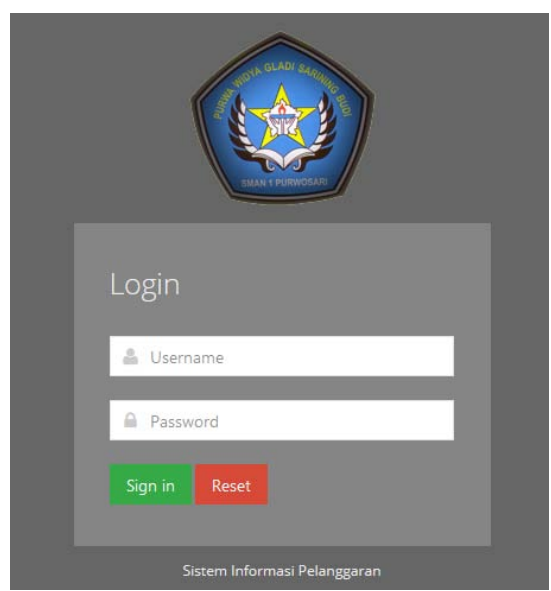

Gambar 3 . Login

\section{b. Tampilan Siswa}

Berikut adalah tampilan dari detail siswa pada hak akses admin

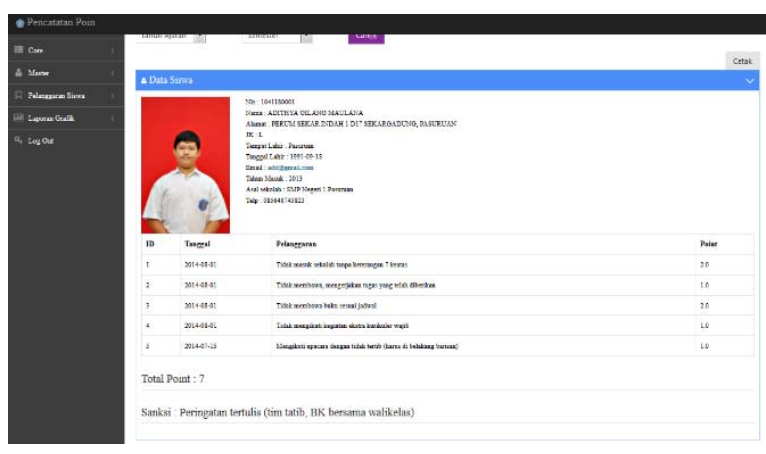

Gambar 4. Tampilan siswa

\section{c. Tampilan Guru/Kepsek}

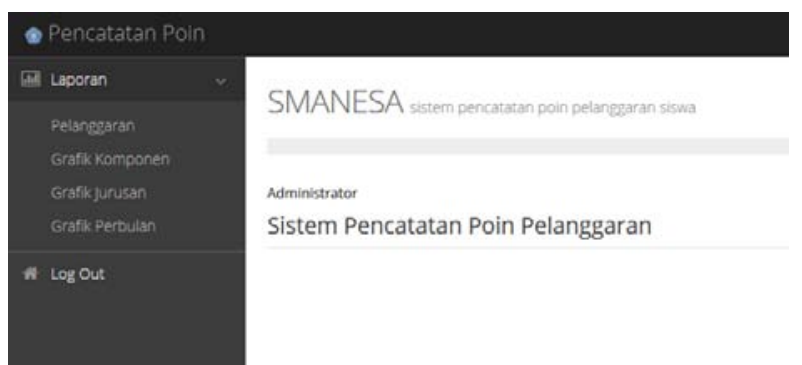

Gambar 5. Tampilan guru 


\section{d. Tampilan Admin}

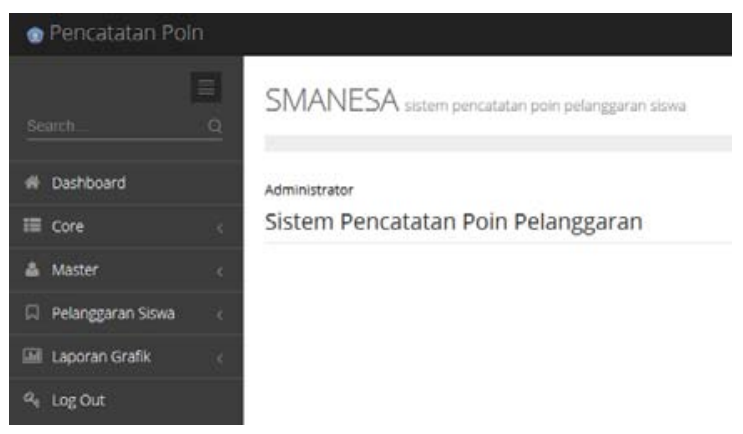

Gambar 6. Tampilan Admin

\section{Pengujian dan Pembahasan}

\subsection{Skenario uji coba}

Skenario uji coba bertujuan agar bisa di ketahui alur dari proses mendapat jumlah pelanggaran yang sudah dilakukan sehingga nantinya mendapatkan hasil yang valid. Berikut adalah skenario uji coba grafik pelanggaran :
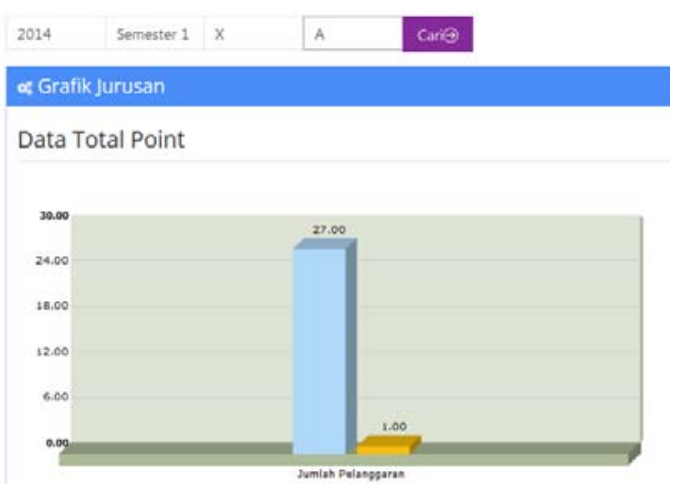

Gambar 7. Grafik pelanggaran

pengujian ini melibatkan tiga jurusan dan tiga siswa dengan jumlah pelanggaran yang berbeda sehinggan pada pengujian ini didapatkan nilai tiap jurusan : Bahasa $=27$, IPA $=1$ dan IPS $=0$

Nilai tersebut valid jika pada pengujian tabel data pelanggaran mempunyai nilai yang sama seperti pada grafik jurusan.

Nilai tersebut valid jika pada gambar 6.2 pengujian tabel data pelanggaran mempunyai nilai yang sama seperti pada grafik jurusan.

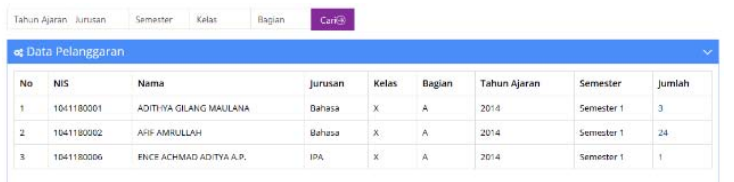

Gambar 8. Data pelanggaran jurusan

\subsection{Pembahasan}

Pada sistem pencatatan poin pelanggaran siswa system dapat menginformasikan data pelanggaran yang dilakukan oleh siswa dan data pelanggaran yang sering dilakukan. Bagi SMA Negeri 1 Purwosari akan menjadi sistem yang sangat penting karena disamping menginformasikan data pelanggaran melalui web bagi guru dan siswanya, sistem ini juga dapat sebuah data grafik dari data pelanggaran. Dengan adanya sistem pencatatan poin pelanggaran siswa ini diharapkan akan membantu sekolah untuk mengurangi pelanggaran - pelanggaran yang sering dilakukan para siswa-siswinya dan juga sebagai bahan guru untuk evaluasi untuk ada didiknya.

\section{Contoh Kasus :}

Menjadikan salah satu siswa menjadi salah satu obyek contoh untuk menentukan sanksi yang didapat.

Penentuan sanksi dilakukan dengan cara menginputkan pelanggaran yang dilakukan oleh siswa sehingga nantinya akan menghasilkan notifikasi sanksi yang akan di dapatkan. Berikut adalah gambar dari penentuan sanksi yang di dapat, berikut mengambil siswa sebagai contoh pengujian

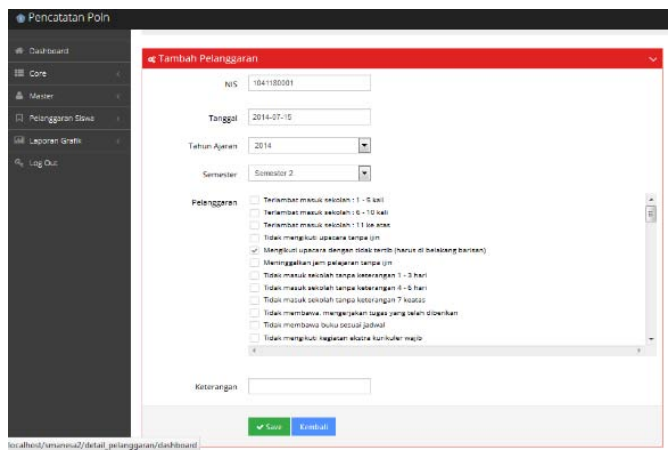

Gambar 9. Input pelanggaran

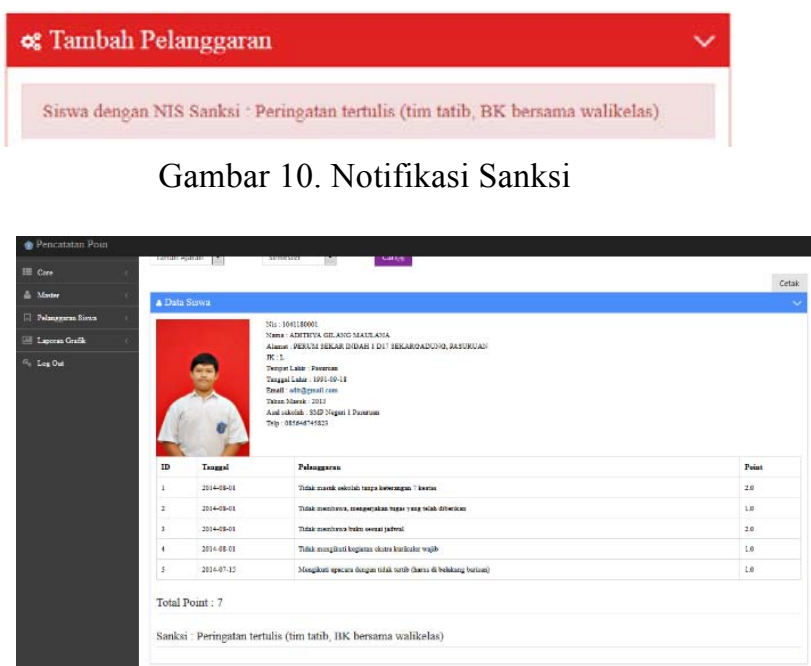

Gambar 11. Detail Siswa 


\begin{tabular}{|c|c|c|c|}
\hline No & NIS & PELANGGARAN & POIN \\
\hline 1 & 1041180001 & Tidak masuk sekolah tanpa keterangan 7 ke atas & 2 \\
\hline 2 & 1041180001 & tidak membawa, mengerjakan tugas yang telah diberikan & 1 \\
\hline 3 & 1041180001 & tidak membawa buku sesuai jadwal & 2 \\
\hline 4 & 1041180001 & Tidak mengikuti kegiatan ekstra kurikuler wajib & 1 \\
\hline 5 & 1041180001 & Mengikuti upaca dengan tidak tertib (harus di belakang barisan) & 1 \\
\hline & & Total & 7 \\
\cline { 2 - 3 } & &
\end{tabular}

Gambar 12. Pelanggaran siswa

Pada gambar 12 menjelaskan secara manual bagaimana proses penjumlahan poin pelanggaran yang di dapat,

$$
\begin{aligned}
\sum \mathrm{P} & =\mathrm{P} 1+\mathrm{P} 2+\mathrm{P} 3+\mathrm{P} 4+\mathrm{P} 5 \\
& =2+1+2+1+1 \\
& =7
\end{aligned}
$$

Total poin itu nantinya akan di sesuaikan dengan range poin sanksi pada gambar 13

\begin{tabular}{|l|l|}
\hline \multicolumn{1}{|c|}{ RANGE POIN } & \multicolumn{1}{c|}{ SANKSI } \\
\hline 1 sampai dengan 5 & Peringatan lisan oleh setiap guru walikelas \\
\hline 5,5 sampai dengan 15 & Peringatan tertulis (tim tatib, BK bersama walikelas) \\
\hline 15,5 sampai dengan 20 & Skorsing / dikembalikan ke orang tua maksimal 4 hari diberi tugas \\
\hline 20,5 sampai dengan 29,9 & Skorsing / dikembalikan ke orang tua maksimal 6 hari diberi tugas \\
\hline 30 sampai dengan 39,5 & Siswa tidak naik kelas. \\
\hline 40 ke atas & Dikembalikan kepada orang tua seterusnya. \\
\hline
\end{tabular}

Gambar 13 Range Sanksi

\section{Kesimpulan dan Saran}

\subsection{Kesimpulan}

Berdasarkan pada hasil perancangan, implementasi, pengujian dan pembahasan terhadap sistem aplikasi yang sudah dibuat, maka diperoleh kesimpulan sebagai berikut :

a. Dengan adanya Sistem Pencatatan Poin Pelanggaran Siswa ini akan lebih memudahkan siswa mendapatkan informasi tentang poin yang didapat.

b. Sistem Pencatatan Poin Pelanggaran Siswa ini akan lebih memudahkan guru untuk mengevaluasi para siswanya serta diharapkan bisa sebagai acuan untuk mengurangi pelanggaran yang dilakukan siswa - siswinya.

\subsection{Saran}

Pada penelitian ini ada beberapa saran yang perlu diberikan, meliputi :

a. Aplikasi sistem pencatatan poin pelanggaran siswa yang dibangun bisa dikembangkan menggunakan berbasis android.

b. Sistem ini dapat dikembangkan lebih lanjut dengan mengintregasikan sistem akademik sehingga memudahkan pengambilan dan rekapitulasi data pelanggaran siswa.

\section{Daftar Rujukan}

Surya, Mohamad. 2003. Psikologi Konseling. Bandung: Pustaka Bani Quraisy.

Rifa'i RC, Achmad \& Tri Anni, Catharina. 2011. Psikologi Pendidikan. Semarang: Universitas Negeri Semarang Press.

Mulyono. 2000. Kesadaran Berbangsa. Bandung: Angkasa.

Slamet dkk. 2008. Pendidikan Kewarganegaraan 3. Jakarta: Pusat Perbukuan Departemen Pendidikan Nasional.

Murniatmo dkk. 1999. Aktualisasi Nilai Budaya Bangsa di Kalangan Generasi Muda Daerah Istimewa Yogyakarta. Yogyakarta: Departemen Pendidikan dan Kebudayaan.

Yanuar A. 2012. Jenis-Jenis Hukuman Edukatif. Jogjakarta: DIVA Press.

S.A., Rosa, dan Shakahudin, M. 2013. Rekayasa Perangkat Lunak Terstruktur dan Berorientasi Objek. Bandung: Informatika

Al-Bahra bin Ladjamudin, (2005), Analisa dan Desain Sistem Informasi, Yogyakarta : Graha Ilmu.

Tim PrimaPena. 2012. Kamus Besar Bahasa Indonesia. Jakarta: Gitamedia Press.

Riyanto, 2011, Membuat Sendiri Aplikasi ECommece dengan PHP dan MySQL

menggunakan CodeIgniter dan JQuery, Penerbit Andi, Yogyakarta 